\title{
Application of the method of complex assessment of energy-ecological-economic efficiency of energy supply systems with cogeneration heat pump installations and peak sources of heat
}

\author{
O. P. Ostapenko \\ Department of Heat Power Engineering, Vinnytsia National Technical University, Vinnytsia, Ukraine \\ Corresponding author. E-mail: ostapenko1208@gmail.com \\ Paper received 29.06.18; Revised 03.07.18; Accepted for publication 05.07.18.
}

\author{
https://doi.org/10.31174/SEND-NT2018-171VI19-11
}

Abstract. The application of the method of complex assessment of energy-ecological-economic efficiency of energy supply systems (ESS) with cogeneration heat pump installations (CHPI) and peak sources of heat (PSH) has been performed, this method has indepth approach to the assessment of energy transformations in ESS elements and enables to provide the substantiated determination of high energy efficient, ecologically safe and economically substantiated operation modes of ESS with CHPI and PSH.

Keywords: methodical fundamentals, energy-ecological-economic efficiency, energy supply system, cogeneration heat pump installation, peak source of heat.

Introduction. In recent years a number of papers were devoted to the problems, studying energy, economic and ecological efficiency of ESS with CHPI [1 - 13]. In [2 7] the number of investigation of assessment of energy and economic efficiency of energy supply systems on the base of steam compressor heat pump installations (HPI) and cogeneration heat pump installations were carried out. In research [4, 8] methodical fundamentals of energyeconomic efficiency assessment of ESS with CHPI of different power levels and peak sources of heat, with the account of complex impact of variable operation modes of ESS, peak sources of heat in ESS, sources of CHPI drive energy and with the account of energy losses in the process of generation, supply and conversion of electric energy, are suggested.

$$
\mathrm{K}_{\mathrm{ESS}}^{\text {compl. }}=\mathrm{K}_{\mathrm{ESS}}+\Delta \mathrm{E}_{\mathrm{i}}^{\mathrm{ESS}}+\Delta \mathrm{EC}_{\mathrm{i}}^{\mathrm{ESS}}=(1-\beta) \cdot \mathrm{K}_{\mathrm{PSH}}+\beta \cdot \mathrm{K}_{\mathrm{CHPI}}+\Delta \mathrm{E}_{\mathrm{i}}^{\mathrm{ESS}}+\Delta \mathrm{EC}_{\mathrm{i}}^{\mathrm{ESS}}
$$

where $\mathrm{K}_{\mathrm{ESS}}$ - complex dimensionless criterion of energy efficiency of ESS with CHPI and PSH from the researches [2 - 11], that used for the determination of highly efficient operation modes of the ESS on condition that $\mathrm{K}_{\mathrm{ESS}}>1$;

$\Delta \mathrm{E}_{\mathrm{i}}^{\mathrm{ESS}}$ - is relative economic efficiency for ESS with CHPI and PSH for $i$-th operation mode of ESS from the researches [4, 8-11];

$\Delta \mathrm{EC}_{\mathrm{i}}^{\mathrm{ESS}}-$ is relative ecologic efficiency for ESS with CHPI and PSH for $i$-th operation mode of ESS from the researches $[8-11]$;

$\beta$ - share of CHPI loading within the frame of ESS from the researches $[2-11]$;

$\mathrm{K}_{\mathrm{PSH}}$ - dimensionless criterion of energy efficiency of PSH within ESS (hot-water fuel-fired boiler (FB), electric boiler (EB), solar collectors, etc.) from the researches [211];

$\mathrm{K}_{\text {CHPI }}$ - dimensionless criterion of CHPI within ESS energy efficiency from the researches [2-13].

As it is noted in the study [2], energy efficient operation modes of ESS with CHPI and PSH will be provided if the indexes of energy efficiency of CHPI and ESS will be $K_{\mathrm{CHPI}}>1$ and $K_{\mathrm{ESS}}>1$. In formula (1) complex dimensionless criterion of energy efficiency of ESS $K_{\text {ESS }}$
Publications review on the subject. In our research [9] methodical fundamentals of complex assessment of energy-ecological-economic efficiency of ESS with CHPI of various power levels and peak sources of heat with the account of complex impact of variable operation modes of ESS, peak sources of heat in ESS, sources of CHPI drive energy and with the account of energy losses in the process of generation, supply and conversion of electric energy are suggested. In our study [9] it is suggested to perform the comprehensive assessment of energy-ecologicaleconomic efficiency of ESS on the base of CHPI and PSH according to complex generalized dimensionless criterion of energy-ecological-economic efficiency of ESS with CHPI and PSH:

is used for the determination of highly efficient operation modes of the ESS on condition that $\mathrm{K}_{\mathrm{ESS}}>1$; index of relative economic efficiency of ESS $\Delta \mathrm{E}_{\mathrm{i}}^{\mathrm{ESS}}$ enables to determine economically valid operation modes of the ESS on condition that $\Delta \mathrm{E}_{\mathrm{i}}^{\mathrm{ESS}}>0$; index of relative ecologic efficiency of ESS $\triangle \mathrm{EC}_{\mathrm{i}}^{\mathrm{ESS}}$ enables to determine ecologically safe operation modes of the ESS with CHPI and PSH on condition that $\Delta \mathrm{EC}_{\mathrm{i}}^{\mathrm{ESS}}>0$, as it is noted in the study [11].

In the study [9] it is determined that ecologically safe, energy efficient and economically valid operation modes of ESS with CHPI and PSH are provided on the condition that $\mathrm{K}_{\mathrm{ESS}}^{\text {compl. }}>1$. Energy efficiency, ecological safety and economic efficiency of the ESS with CHPI and PSH increase with the increase of this index.

Objective. Aim of the research is the application of the method of complex assessment of energy-ecologicaleconomic efficiency of energy supply systems with cogeneration heat pump installations and peak sources of heat, that has in-depth approach to the assessment of energy transformations in ESS elements, enabling to provide the substantiated determination of high energy efficient, ecologically safe and economically substantiated operation modes of ESS with CHPI and PSH.

Materials and methods. The research contains the ex- 
amples of application of the method of complex assessment of energy-ecological-economic efficiency of ESS with PSH and small power CHPI, using the heat of sewage. Efficiency of ESS with steam compressor HPI of small power with cogeneration drive from gas-piston engine-generator (GPE) was studied. Electric or fuel-fired boiler houses were provided to be used as peak sources of heat in ESS. The investigated ESS can completely or partially provide auxiliary needs in electric energy and provide the consumers needs in heating and hot water supply. Schemes of the ESS with CHPI and PSH are presented in works $[1,14]$.

Methodical fundamentals for energy, ecological and economic efficiency assessment of ESS with CHPI and PSH are presented in the studies [4 - 10]. Methodical fundamentals for assessment of energy, ecological and economic aspects of ESS efficiency with CHPI on natural and industrial sources of heat are suggested in the research [15 - 17].

Substantiation of the method of complex assessment of energy-ecological-economic efficiency of ESS with CHPI and PSH is presented in [11]. Principles for selection of the areas of energy-ecological-economic efficiency of ESS with CHPI and PSH are presented in the study [10].

Results and discussion. Application of the suggested in [9] methodical fundamentals for comprehensive assessment of energy-ecological-economic efficiency of ESS with CHPI and PSH will be demonstrated on the specific examples.

Figs. 1 and 2 show the results of complex assessment of energy-ecological-economic efficiency of ESS with CHPI and PSH. In our research the values of the dimensionless criterion of energy-ecological-economic efficiency of ESS with of CHPI and PSH are determined on conditions of CHPI loading share change in the range of $\beta=0,1 \ldots 1,0$. The study was carried out for energy efficient operation modes of CHPI with $\mathrm{K}_{\mathrm{CHPI}}=1,1 \ldots 2,1$ (on conditions of maximum efficiency of GPE) and with $\mathrm{K}_{\mathrm{CHPI}}=1,1 \ldots 1,6$ (on conditions of minimum efficiency of GPE), on the base of the research results [2, 3].

Fig. 1 shows the area of energy-economical efficient and ecologically safe ESS operation, using the heat of sewage, with CHPI of small power and peak electric boiler with the consumption of electric energy from CHPI. This area is determined by the index of energy-ecologicaleconomic efficiency of ESS with CHPI and PSH from the formula (1) on conditions of minimal efficiency of GPE and peak electric boiler. In our research, according to [2, $3]$, the following values are taken into account: value of GPE efficiency factor $\eta_{\mathrm{EM}}=0,31$, value of electric motor efficiency with the account of energy losses in the control unit of the motor $\eta_{\mathrm{ED}}=0,8$. Electric boiler house with $\eta_{E B}=0,9$ is provided to be peak source of heat in ESS. The value of dimensionless criterion of electric boiler energy efficiency in case of electric energy consumption from CHPI, according to [2], is $\mathrm{K}_{\mathrm{PSH}}^{\mathrm{EB}}=0,223$. In order to assess the relative ecological efficiency of ESS with CHPI and PSH as the alternative source of heat the electric boiler house of corresponding power was provided.
Fig. 2 shows the area of energy-economical efficient and ecologically safe operation of ESS, using the heat of sewage water, with CHPI of small power and peak gasfired boiler. This area is defined by the index of energyecological-economic efficiency of ESS with CHPI and $\mathrm{PSH}$ from the formula (1) on conditions of maximum efficiency of GPE and peak fuel-fired boiler. In our research, according to $[2,3]$, the following values are taken into account: value of GPE efficiency factor $\eta_{\mathrm{EM}}=0,42$ and value of electric motor efficiency with the account of energy losses in the control unit of the motor $\eta_{\mathrm{ED}}=0,8$. Fuel-fired boiler house with $\eta_{\mathrm{FB}}=0,9$ is provided by peak source of heat in ESS. The value of dimensionless criterion of fuel-fired boiler energy efficiency, according to [2], is $\mathrm{K}_{\mathrm{PSH}}^{\mathrm{FB}}=0,9$. In order to assess the relative ecological efficiency of ESS with CHPI and PSH the gasfired boiler house of corresponding power was provided as the alternative source of heat.

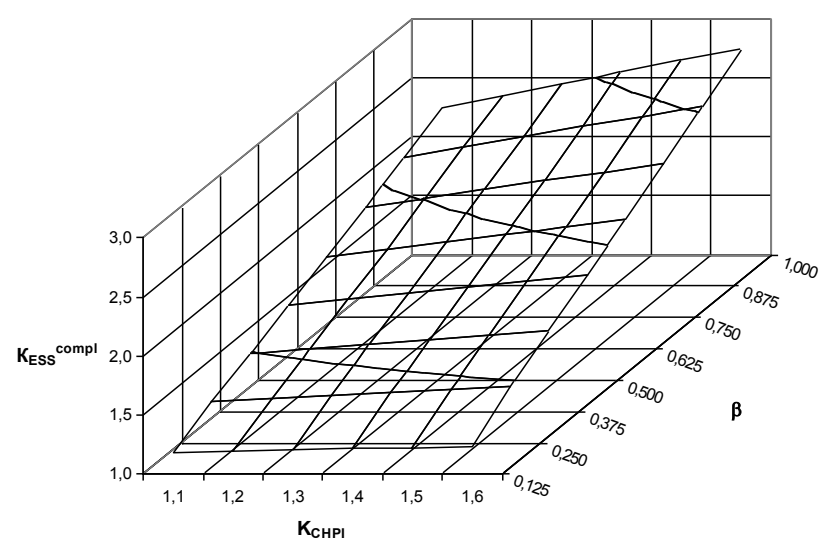

Fig. 1 - Area of energy-economical efficient and ecologically safe operation of ESS, using the heat of sewage, with CHPI of small power and peak electric boiler, on conditions of minimal efficiency of GPE and peak electric boiler and consumption of electric energy from CHPI

As it is seen from Fig. 1, on conditions of: $K_{\mathrm{CHPI}}>1,1$ and $\Delta \mathrm{E}_{\mathrm{i}}^{\mathrm{ESS}}>0$ and $\Delta \mathrm{EC}_{\mathrm{i}}^{\mathrm{ESS}}>0$ and $\mathrm{K}_{\mathrm{ESS}}^{\text {compl. }}>1$, dependence, shown in Fig. 1, determine the area of energyeconomical efficient and ecologically safe operation of ESS, using the heat of sewage, with CHPI of small power and peak electric boiler, on conditions of minimum efficiency of GPE and electric boiler and consumption of electric energy from CHPI.

As it is seen from Fig. 2, on conditions of: $\mathrm{K}_{\mathrm{CHPI}}>1,1$ and $\Delta \mathrm{E}_{\mathrm{i}}^{\mathrm{ESS}}>0$ and $\Delta \mathrm{EC}_{\mathrm{i}}^{\mathrm{ESS}}>0$ and $\mathrm{K}_{\mathrm{ESS}}^{\text {compl. }}>1$, dependence, shown in Fig. 2, determine the area of energy-economical efficient and ecologically safe operation of ESS, using the heat of sewage, with CHPI of small power and peak fuel-fired boiler, on conditions of maximum efficiency of GPE and fuel-fired boiler.

Under such conditions, the above-mentioned ESS can be recommended as energy-economical efficient and ecologically safe ESS. This ESS can be competitive with modern high efficient electric and fuel-fired boilers in the systems of heat and energy supply.

The suggested in studies $[4-11]$ methodical funda- 
mentals allow to determine the areas of high energyeconomic efficiency and ecologically safe operation of ESS with CHPI and PSH and develop recommendations of high efficient operation of ESS with CHPI and PSH. For practical application of the suggested in studies [4-
11] methodical fundamentals for comprehensive assessment of energy-ecological-economic efficiency of different variants of ESS with CHPI and PSH, we propose to use the results, obtained in the research [1 - 13, 15-17].

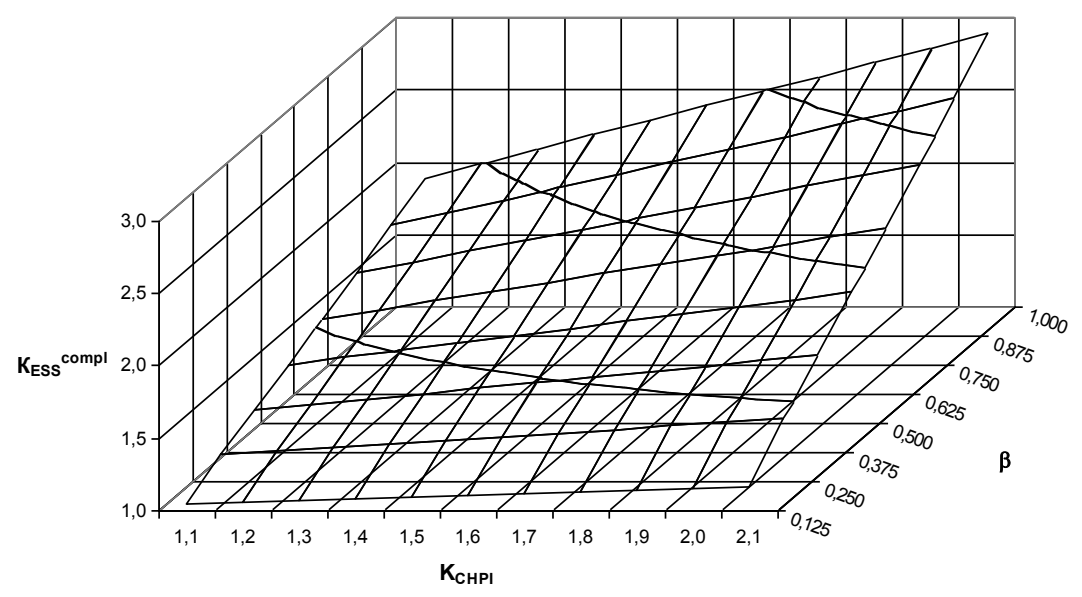

Fig. 2 - Area of energy-economical efficient and ecologically safe operation of ESS, using the heat of sewage, with CHPI of small power and peak fuel-fired boiler, on conditions of maximum efficiency of GPE and peak fuel-fired boiler

Conclusions. In this paper the application of the method of complex assessment of energy-ecological-economic efficiency of ESS with CHPI and PSH has been performed; this method has in-depth approach to the assessment of energy transformations in ESS elements and enables to provide the substantiated determination of high energy efficient, ecologically safe and economically substantiated operation modes of ESS with CHPI and PSH.

The research contains the examples of application of the method of complex assessment of energy-ecologicaleconomic efficiency of ESS with PSH and small power CHPI, using the heat of sewage. In our research, on conditions of: $\mathrm{K}_{\mathrm{CHPI}}>1,1$ and $\Delta \mathrm{E}_{\mathrm{i}}^{\mathrm{ESS}}>0$ and $\Delta \mathrm{EC}_{\mathrm{i}}^{\mathrm{ESS}}>0$ and $\mathrm{K}_{\mathrm{ESS}}^{\mathrm{compl}}>1$, was determined the area of energyeconomical efficient and ecologically safe operation of
ESS with CHPI of small power and peak electric boiler, on conditions of minimum efficiency of GPE and electric boiler and consumption of electric energy from CHPI. On conditions of: $\quad K_{\text {CHPI }}>1,1$ and $\Delta \mathrm{E}_{\mathrm{i}}^{\text {ESS }}>0$ and $\Delta \mathrm{EC}_{\mathrm{i}}^{\mathrm{ESS}}>0$ and $\mathrm{K}_{\mathrm{ESS}}^{\mathrm{compl}}>1$, in our research was determined the area of energy-economical efficient and ecologically safe operation of ESS with CHPI of small power and peak fuel-fired boiler, on conditions of maximum efficiency of GPE and fuel-fired boiler. Under such conditions, the above-mentioned ESS can be recommended as energy-economical efficient and ecologically safe ESS. This ESS can be competitive with modern high efficient electric and fuel-fired boilers in the systems of heat and energy supply.

\section{REFERENCES}

1. Tkachenko, S. Y.; Ostapenko, O. P. Steam compressor heat pump installations in heat supply systems, monograph, Vinnytsia : UNIVERSUM-Vinnytsia, 2009, 176 p. (in Ukrainian)

2. Ostapenko, O. P. Energy efficiency of energy supply systems, based on combined cogeneration heat pump installations and peak sources of heat; electronic resource, Scientific Works of Vinnytsia National Technical University, 2016, № 1, available at: http://works.vntu.edu.ua/index.php/ works/article/view/462/464.

3. Ostapenko, O. P.; Leshchenko, V. V.; Tikhonenko, R. O. Energy efficiency of energy supply systems, based on combined cogeneration heat pump installations; electronic resource, Scientific Works of Vinnytsia National Technical University, 2015, № 4, available at: http://works.vntu.edu.ua/index.php/ works/article/view/451/453.

4. Ostapenko, O. P.; Portnov, V. M.; Voloshyn, A. D. Indices of energy-economic efficiency of energy supply systems on the base of cogeneration-heat-pump installations and peak sources of heat, Electronic scientific edition of the materials of XLVI scientific-engineering conference, held in Vinnytsia National Technical University (March 22 - 24, 2017, Vinnytsia), available at: https://conferences.vntu. edu.ua/index.php/all-fbtegp/all-fbtegp-

2017/paper/view/2875/2248. (in Ukrainian)

5. Ostapenko, O. P. Methodical fundamentals of complex assessment of energy efficiency of steam compressor heat pump plants with electric and cogeneration drive, Scientific Works of Odesa National Academy of Food Technologies, 2015, vol. 47, part 2, p. 157 - 162. (in Ukrainian)

6. Ostapenko, O. P. Complex evaluation of energy efficiency of steam compressor heat pump plants with cogeneration drive, electronic resource, Scientific Works of Vinnytsia National Technical University, 2015, № 3, available at: http://works.vntu.edu.ua/index.php/works/article/view/36/36.

7. Ostapenko, O. P. Scientific basis of evaluation energy efficiency of heat pump plants, monograph, Saarbrücken, LAP LAMBERT Academic Publishing, 2016, 64 p.

8. Ostapenko, O. P. Methodical fundamentals of energy economical efficiency assessment of energy supply systems with cogeneration heat pump installations and peak sources of heat, Scientific Works of Odesa National Academy of Food Technologies, 2017, vol. 81, part 1, p. 136 - 141. (in Ukrainian)

9. Ostapenko, O. P. Methodical fundamentals of complex assessment of energy-ecological-economic efficiency of energy supply systems with cogeneration heat pump installations and peak sources of heat, electronic resource, Scientific Works of Vinnytsia National Technical University, 2017, № 3, available 
https://works.vntu.edu.ua/index.php/works/article/view/510/5 09.

10. Ostapenko, O. P. Principles for selection of the areas of energy-ecological-economic efficiency of energy supply systems with cogeneration heat pump installations and peak sources of heat, Proceedings of the Second International Scientific and Practical conference «Applied Scientific and Technical Research -2018» (April 5-8, 2018, Academy of Technical Sciences of Ukraine, Ivano-Frankivsk city), IvanoFrankivsk : Forte Symphony, 2018, p. 69.

11. Ostapenko, O. P. Substantiation of the method of complex assessment of energy-ecological-economic efficiency of energy supply systems with cogeneration heat pump installations and peak sources of heat, Scientific Works of Vinnytsia National Technical University, 2018, № 1.

12. Ostapenko, O. P.; Leshchenko, V. V.; Tikhonenko, R. O. Energy advantages of application of steam compressor heat pumps with electric and cogeneration drive, electronic resource, Scientific Works of Vinnytsia National Technical University, 2015, № 1, available at: http://works.vntu.edu.ua/ index.php/works/ article/view/437/435.

13. Ostapenko, O. P.; Leshchenko, V. V.; Tikhonenko, R. O. Energy efficiency of steam compressor heat pumps with electric and cogeneration drive, electronic resource, Scientific Works of Vinnytsia National Technical University, 2014,
№ 4, available at: http://works.vntu.edu.ua/ index.php/works/article/view/25/25.

14. Ostapenko, O. P. Refrigeration equipment and technology. Heat pumps, tutorial, Vinnytsia : VNTU, 2015, 123 p. (in Ukrainian)

15. Ostapenko, O. P.; Valigura, I. O.; Kovalenko, A. D. Energy ecological efficiency of heat pumping stations, operating on natural and industrial sources of heat at variable operation modes, electronic resource, Scientific Works of Vinnytsia National Technical University, 2013, № 2, available at: https://works.vntu.edu.ua/index.php/works/article/view/376/3 74.

16. Ostapenko, O. P.; Bakum, Y. V.; Yuschishina, A. V. Energy, ecology and economy aspects of the efficiency of heat power stations operating on natural and industrial heat sources, electronic resource, Scientific Works of Vinnytsia National Technical University, 2013, № 3, available at: https://works.vntu.edu.ua/index.php/works/article/view/384/3 82.

17. Ostapenko, O. P.; Shevchenko, O. V.; Bakum, O. V. Energy efficiency of heat pumping station $\mathrm{s}$ with different heat sources on condition of variable operation modes, electronic resource, Scientific Works of Vinnytsia National Technical University, 2013, № 4, available at: https://works.vntu.edu.ua/ index.php/works/article/view/394/392.

Применение метода комплексной оценки энерго-эколого-экономической эффективности систем энергоснабжения с когенерационно-теплонасосными установками и пиковыми источниками теплоты

\section{О. П. Остапенко}

Аннотация. Представлено применение метода комплексной оценки энерго-эколого-экономической эффективности систем энергоснабжения (СЭ) с когенерационно-теплонасосными установками (КТНУ) и пиковыми источниками теплоты (ПИТ), этот метод имеет углублённый подход к оценке энергопреобразований в элементах СЭ и позволяет обеспечить обоснованное определение высокоэнергоэффективных, экологически безопасных и экономически обоснованных режимов работы СЭ с КТНУ и ПИТ.

Ключевые слова: методические основы, энерго-эколого-экономическая эффективность, система энергоснабжения, когенерационно-теплонасосная установка, пиковый источник теплоты. 